\title{
The Effect of Leverage, Capital Intensity and Deferred Tax Expense on Tax Avoidance
}

\author{
Cicik Suciarti \\ Telkom University \\ Elly Suryani \\ Telkom University \\ Kurnia \\ Telkom University
}

\begin{abstract}
This research was conducted to determine the simultaneous and partial effect of Leverage, Capital Intensity and Deferred Tax Expense on Tax Avoidance in the automotive subsector companies listed on the Indonesia Stock Exchange (IDX) during 2012-2018. The sampling technique used was purposive sampling. The method of data analysis uses panel data regression analysis using Eviews 10 software by conducting several stages of testing. The results of this study indicate that leverage, capital intensity, and deferred tax expense simultaneously significantly affect tax avoidance. Capital intensity partially has a significant effect on tax avoidance in a negative direction. Meanwhile, leverage and deferred tax expense partially have no significant effect on tax avoidance.
\end{abstract}

Keywords: leverage; capital intensity; deferred tax expense; tax avoidance

\section{Introduction}

Taxes are the primary source of state revenue used to pay state expenditure. As for the company, tax is an expense that will reduce the company's profit. Differences in interests from the side of the government who want a large and continuous amount of tax payments by companies are in contrast to companies that want minimum tax payments (Hardika in Kurniasih and Sari, 2013). Legal efforts to reduce taxes are called tax avoidance. In contrast, efforts to reduce taxes illegally are called tax evasion. Tax Avoidance is an effort done legally and safely for taxpayers without conflicting with applicable taxation provisions where the methods and techniques used tend to exploit the weaknesses contained in the laws and tax regulations themselves to reduce the amount tax payable (Pohan, 2018).

One case at PT. Garuda Metalindo which on the company's balance sheet shows an increase in the amount of debt. In the financial statements, the value of short-term bank loans reached up to $\mathrm{Rp} 200$ billion in June 2016. The amount increased from the end of December 2015 of Rp 48 billion. PT. Garuda Metalindo uses fund from debt to avoid paying company taxes. The company is suspected of making tax avoidance from administration to activities to avoid tax obligations. With the fund from debt, there will be interest expense. The high-interest expense will have the effect of reducing the tax expense

There are still many companies in Indonesia that do not fulfil their tax obligations by minimizing the company's tax expense. An indication of companies avoiding taxes can be identified from the funding policies adopted by the company. One of the policies for funding is leverage, which is the level of debt used by companies to finance operational activities. With the debt will cause interest expense. Interest expense that arises because of the debt will be a deduction from the company's net profit and will later reduce tax. If the company is more relies on debt than equity for operational activities, then interest expense is taxes deductible (Richardson and Lanis, 2007). The higher the debt the company has, the higher the tax avoidance is indicated. The purpose of doing tax avoidance is the funds that should be used to pay taxes, are used to pay debts and interest expenses to finance the activities of the company. Companies that have a high tax expense will prefer to owe for the sake of 
minimizing the tax expense (Alfina et al., 2018).

Investment decisions are also things that can affect tax payments. Depreciation of fixed assets is an essential part of company costs (Ribeiro et al., 2015). Ownership of fixed assets by companies can reduce the tax payments paid due to the depreciation costs attached to these fixed assets. Depreciation costs can be used by managers to minimize the taxes paid by companies. Management will use idle company funds to buy fixed assets as an investment in order to get a profit that is depreciation costs that are useful as tax deductions (Dharmadi, 2013 in Dharma and Noviari, 2017).

Based on PSAK no. 46 tax allocation between periods begins with the company having to recognize deferred tax assets and liabilities that must be disclosed on the balance sheet. The recognition of deferred tax assets and liabilities is recognition of the future tax consequences of the cumulative effect of temporary differences in recognition of income and expenses for accounting and fiscal purposes. In the asset-liability approach, a temporary difference is a difference between the tax base (DPP) of an asset or liability and the carrying value of the asset or liability. The effects of temporary changes reflected in an increase or decrease in deferred tax assets and liabilities must be treated as deferred tax expenses or deferred tax income and disclosed in the current year's income statement together with current tax expenses and presented separately. (Meiza, 2015). Plesko (2002) in Phillips et al., (2003).

It was revealed that the higher the difference between fiscal earnings and accounting earnings shows the higher the management discretion. The amount of discretion will affect the deferred tax burden and be able to be used to detect tax avoidance practices. So it can be concluded the higher the deferred tax reporting or deferred tax expenses of the company as measured by the inter-period tax allocation will affect corporate tax avoidance, the higher the inter-period allocation means the smaller the practice of tax avoidance by the company. Based on the background that has been described and the differences from the results of previous studies, the author wants to conduct further research with the title The Effect of Leverage, Capital Intensity and Deferred Tax Expense, Against Tax Avoidance
(An Empirical Study of Automotive Sub Sector Companies Listed on the Indonesia Stock Exchange (IDX) 2012-2018)

\section{Literature Review and Hypothesis Development}

\section{Leverage and Tax Avoidance}

Leverage is a ratio that measures how far the company uses debt for financing. With the debt will cause interest expense. Interest expense that arises because of the debt will be a deduction from the company's net profit and will later reduce tax. If the company is more relies on debt than equity for operational activities, then interest expense is taxes deductible while dividends are not. Companies with high leverage will have low ETR (Richardson and Lanis, 2007). Therefore the frame of mind of leverage on tax avoidance has a positive effect. This opinion supports the results of previous research conducted by Richardson and Lanis (2007).

\section{Hypothesis 1: Leverage has a significant positive effect on Tax Avoidance}

\section{Capital Intensity and Tax Avoidance}

According to Adisamartha and Noviari (2015), capital intensity is a ratio that indicates the intensity of ownership of a company's fixed assets compared to total assets. Capital intensity describes how much the company invests its assets in the form of fixed assets and inventories. Fixed assets allow companies to reduce taxes due to depreciation (Rodríguez and Arias, 2012) Management will invest in fixed assets by using the company's unused funds to obtain benefits in the form of depreciation costs that can be used as tax deductions (Dharmadi, 2013 in Dharma and Noviari, 2017). Therefore, companies with many fixed assets will have a low tax expense because of depreciation from fixed assets every year (Rodríguez and Arias, 2012). This opinion supports the results of previous research conducted by Dharma and Noviari (2017) that capital intensity has a positive effect on tax avoidance.

Hypothesis 2: Capital Intensity has a significant positive effect on Tax Avoidance 


\section{Deferred Tax Expense and Tax Avoidance}

Based on PSAK no. 46 tax allocation between periods begins with the company having to recognize deferred tax assets and liabilities that must be disclosed on the balance sheet. The recognition of deferred tax assets and liabilities is recognition of the future tax consequences of the cumulative effect of temporary differences in recognition of income and expenses for accounting and fiscal purposes. In the assetliability approach, what is meant by a temporary difference is the difference between the tax base (DPP) of an asset or liability and the carrying value of the asset or liability. The effects of temporary changes reflected in an increase or decrease in deferred tax assets and liabilities must be treated as deferred tax expenses and disclosed in the current year's profit and loss together with current tax expenses and presented separately (Meiza, 2015).

Plesko (2002) in Phillips et al., (2003) revealed that the higher the difference between fiscal earnings and accounting earnings shows the higher the management discretion. The amount of discretion will affect the deferred tax expense and can be used to detect tax avoidance practices. So it can be concluded that the higher the deferred tax reporting or deferred tax expenses of the company as measured by the allocation of taxes between periods will affect corporate tax avoidance, the higher the interperiod allocation means the smaller the practice of corporate tax avoidance. It is in line with the results of research conducted by Meiza (2015) showing that deferred tax expense has a significant negative effect on tax avoidance.

Hypothesis 3: Deferred tax expense has a significant negative effect on Tax Avoidance

\section{Methods}

\section{Sampling}

The research uses quantitative methods. The data for this research uses secondary data. The sampling method used is nonprobability sampling, namely by purposive sampling. The population in this study is the automotive subsector company listed on the Indonesia Stock Exchange (IDX) in 2012-2018. There are criteria used to determine the sample: (1)Automotive sub-sector companies listed on the Indonesia Stock Exchange (IDX) during 2012-2018; (2)The companies were successively listed on the Indonesia Stock Exchange during 2012-2018; (3)Automotive sub-sector companies which successively published Financial Statements during 20122018; (4)Companies that did not experience losses during the 2012-2018 period.

\section{Measure}

In this study, to measure tax avoidance researchers used the Effective Tax Rate (ETR) proxy. According Rodríguez and Arias (2012) ETR can be measured by the formula:

$$
\text { ETR }=\frac{\text { Tax Expense }}{\text { Earning Before Income } \operatorname{Tax}}
$$

The first independent variable is leverage. One of the leverage ratios is the debt to asset ratio. The formula of debt to asset ratio according to Rodríguez and Arias (2012) is :

$D A R=\frac{\text { Total Debt }}{\text { Total Assets }}$

The second independent variable is capital intensity. According to Dharma and Noviari (2017) capital intensity is measured using the following formula :

$$
C I=\frac{\text { Total Fix Assets }}{\text { Total Assets }}
$$

The third independent variable is deferred tax expense. According to Meiza (2015) deferred tax expense is calculated using the following formula:

$$
D T E=\frac{(D T E p-D T E p-1)}{T A p-1}
$$

Where:

DTEp =Deferred tax expense on the financial statements ending in year $p$. DTEp-1 =Deferred tax expense on financial statements ending year $\mathrm{p}-1$. TAp-1 =Total assets in year $\mathrm{p}-1$.

\section{Analysis}

This research uses panel regresion model due to panel data is combination of cross section data 
with time series data. For panel data regression, the classic assumption tests used are multicollinearity and heteroscedasticity tests. The Provisions if there is no multicollinearity the correlation value between all independent variables tested $<0,9$. For heteroscedasticity test if the probability value $>0,05$ then the data is not heteroscedasticity. Simultaneous Test (F Test) and Partial Test (T Test) have the level of significance $(\alpha)$ is 0,05 (Sarwono 2016). The software used in data analysis is Eviews 10.

\section{Results}

\section{Descriptive Statistics}

The sample used is the automotive sub-sector companies listed on the Indonesia Stock Exchange for the period 2012-2018. The sampling technique in this study used purposive sampling.

Table 1. Descriptive Statistic

\begin{tabular}{lrrrr}
\hline & Tax Avoidance & Leverage & Capital Intensity & \multicolumn{2}{c}{$\begin{array}{c}\text { Deferred Tax } \\
\text { Expense }\end{array}$} \\
\hline Maximum & 0,5322 & 0,5073 & 0,5999 & 0,0082 \\
Minimum & 0,1009 & 0,1161 & 0,1637 & $-0,0086$ \\
Mean & 0,2326 & 0,3259 & 0,3572 & $-0,0002$ \\
Stdev & 0,0736 & 0,1098 & 0,1590 & 0,0033 \\
\hline
\end{tabular}

In the results of the descriptive statistic above, the maximum value of tax avoidance is 0,5322 . It identifies that the company with the maximum value does tax avoidance because the ETR value $>0,25$. The mean value of tax avoidance is 0,2326 , and the standard deviation is 0,0736 , which means the mean value is greater than the standard deviation, so the data is homogeneous. The mean value of leverage is 0,3259 . It is considered quite good, because most of the assets of companies in the automotive sub-sector are financed through equity. The standard deviation leverage is 0,1098 , which means the mean value is greater than the standard deviation, so the data is homogeneous. The mean capital intensity value is 0,3572 . It means that the average amount of total company assets consists of $35.72 \%$ of fixed assets. It is possible because the automotive sub-sector is one of the manufacturing industries that has quite a lot of fixed assets. The standard deviation of capital intensity is 0,1590 , which means the mean value is greater than the standard deviation, so the data is homogeneous. The mean value for the deferred tax expense is $-0,0002$, and the standard deviation is 0,0033 , which means the mean value is smaller than the standard deviation value, so the data is heterogeneous.

\section{Multicollinearity Test}

Multicollinearity test is needed to determine whether there are similarities between independent variables with others (Sujarweni, 2015). There would be no multicollinearity provision if the correlation value among all independent variables tested $<0.9$ (Sarwono, 161:2016). The following are the results of the Multicollinearity Test :

Table 2. Output Multicollinearity Test

\begin{tabular}{cccc} 
& LEV & CI & DTE \\
\hline LEV & 1.000000 & -0.547174 & 0.038987 \\
CI & -0.547174 & 1.000000 & 0.044354 \\
DTE & 0.038987 & 0.044354 & 1.000000 \\
\hline
\end{tabular}

In Table 2 shows a multicollinearity test results, based on data from the test results show that the correlation value between all independent variables tested $<0,9$. So it can be concluded that this study did not occur multicollinearity. 


\section{Heteroscedasticity Test}

Heteroscedasticity test is performed to test the difference in the residual variance of one observation period to another observation period (Sujarweni, 2015). The following are the results of the Heteroscedasticity Test:

Table 3. The output of Heteroscedasticity Test

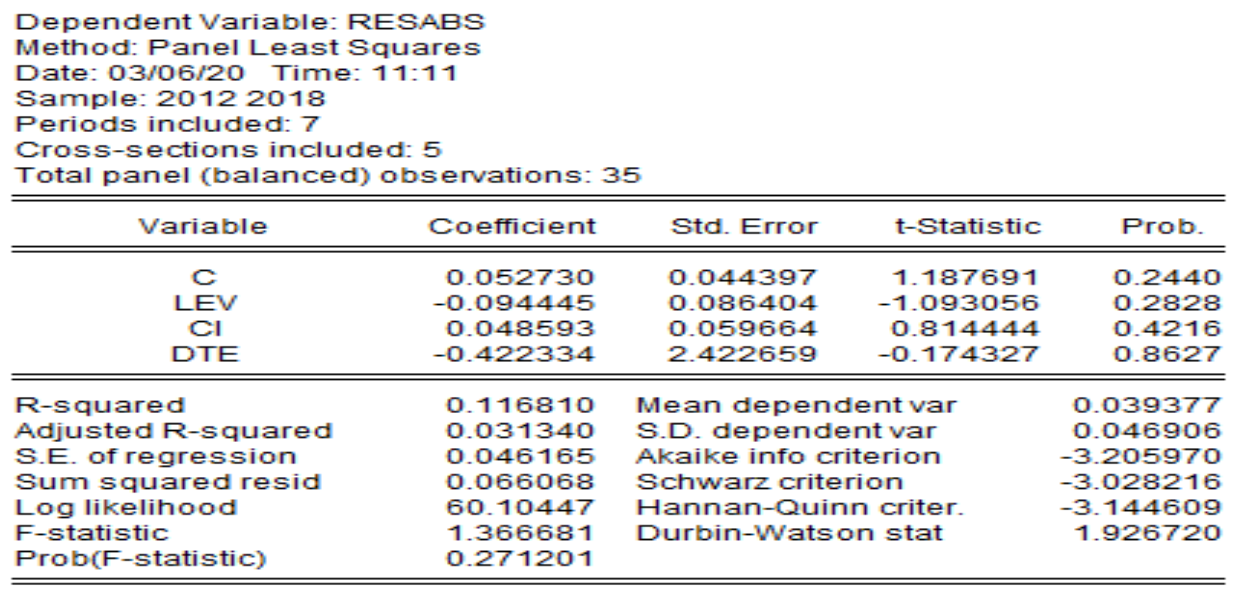

In Table 3 shows the results of heteroscedasticity test with a probability value $>0,05$ it can be concluded that the data are not heteroscedasticity or heteroscedasticity does not occur.

Analysis of Panel Regression Model
A panel data (pooled data) is a data set that contains individual sample data over a specified time period. By combining time-series data and cross-section, data will be able to increase the number of observations significantly. This regression purpose is to test simultaneously and partially effect. Below is the result of a common effect model test using Eviews 10 software.

Table 4. Panel Regresion

\begin{tabular}{|c|c|c|c|c|}
\hline $\mathrm{C}$ & 0.122034 & 0.062055 & 1.966537 & 0.0582 \\
\hline LEV & 0.058408 & 0.120770 & 0.483625 & 0.6321 \\
\hline $\mathrm{Cl}$ & 0.253963 & 0.083394 & 3.045343 & 0.0047 \\
\hline DTE & -5.302858 & 3.386230 & -1.566006 & 0.1275 \\
\hline R-squared & 0.299156 & Mean depen & ent var & 0.232626 \\
\hline Adjusted R-squared & 0.231332 & S.D. depend & at var & 0.073599 \\
\hline S.E. of regression & 0.064527 & Akaike info o & erion & -2.536266 \\
\hline Sum squared resid & 0.129074 & Schwarz crit & ion & -2.358512 \\
\hline Log likelihood & 48.38466 & Hannan-Qui & criter. & -2.474906 \\
\hline F-statistic & 4.410790 & Durbin-Wats & n stat & 2.367936 \\
\hline Prob(F-statistic) & 0.010743 & & & \\
\hline
\end{tabular}


Based on the test results of the significance of the common effect model in Table 4 , it can be formulated that the panel data regression equation is as follows:

$$
\begin{aligned}
& \text { TA }=0,122034+0,058408 \text { LEV }+0,253963 \\
& \text { CI }-5,302858 \text { DTE }+\varepsilon, \text { where }: \\
& \text { TA } \quad=\text { Tax Avoidance measured by ETR } \\
& \text { LEV } \quad=\text { Leverage } \\
& \text { CI } \quad=\text { Capital Intensity } \\
& \text { DTE } \quad=\text { Deferred Tax Expense } \\
& \varepsilon \quad=\text { Error Term }
\end{aligned}
$$

\section{Simultaneous Test (F Test)}

According to Sarwono (2016), the F statistical test is used as an alternative to simultaneous hypothesis testing. Based on the test results of the common effect model in Table 4 , it is known that the Adjusted R-squared value in this research model is 0.231332 or $23.13 \%$ with a Prob (F-statistic) level of 0.010743 where the value $<0.05$. It can be concluded that leverage, capital intensity and deferred tax expense have a significant effect simultaneously on tax avoidance. In addition, the independent variable leverage, capital intensity and deferred tax expense are able to explain the dependent variable tax avoidance as measured by the effective tax rate in the automotive subsector company by $23,13 \%$, while the remaining $76,87 \%$ is explained by other variables outside this study.

\section{Partial Test (T Test)}

According to Sarwono (2016:33) t test is basically used as a partial or individual hypothesis test when using independent variables or predictors more than one. Based on the $t$ statistical test that has been presented in Table 4, it can be concluded that: Probability value of Leverage (LEV) is 0,6321. This shows that $0,6321>0,05$ then leverage partially has no significant effect on Tax Avoidance. Probability value of Capital Intensity 0,0047. This shows that $0,0047<0,05$ then the Capital Intensity partially has a significant influence on Tax Avoidance. Probability value of Deferred Tax Expense is 0,1275. This shows that 0,1275> 0,05 then the Deferred Tax Expense partially has no significant effect on Tax Avoidance.

\section{Discussion}

Leverage partially has no significant effect on tax avoidance in the automotive subsector companies for the period 2012 - 2018. So, hypothesis 1 is rejected. This is because the sample of companies studied is considered capable of paying off all obligations both shortterm or long-term obligations with collateral for assets owned by the company and can fund its operational activities through assets owned compared to debt. The results of this study are in line with the study of Sabli \& Noor (2012), Irianto et al., (2017), Darmawan \& Sukartha (2014) and Yunanda \& Saifudin (2016) which states Leverage has no significant effect on Tax Avoidance.

Capital Intensity partially has a significant negative effect on Tax Avoidance in automotive subsector companies in the period 2012 - 2018. So, hypothesis 2 is rejected. It is possible because the sample of the company used is the automotive subsector company which is one of the manufacturing industries. The company's fixed assets are very influential for production capacity in the manufacturing industry because the higher the fixed assets owned, the higher the production capacity. Increased sales mean increased income which results in increased corporate tax expense to be paid. The results of this study are in line with the study of Muzakki \& Darsono (2015), Darmadi \& Zulaikha, (2013) and Dharma \& Ardiana (2016) which states that Capital Intensity has a negative effect on Tax Avoidance

Deferred Tax Expense partially has no effect on Tax Avoidance in automotive subsector companies in the period 2012 - 2018. So, hypothesis 3 is rejected. According to Plesko (2002) in Phillips et al., (2003), the higher difference between fiscal earnings and accounting earnings shows the higher management discretion. The amount of discretion will affect the deferred tax burden and be able to be used to detect tax avoidance practices. However, the sample of companies studied is considered to have a small difference between fiscal earnings and accounting earnings or has a low value of management descent. So, that low management descent cannot detect tax avoidance practices. The results of this study are in line with the study of Kalbuana et al., (2017), Tuerfia, (2017) and 
Pohan (2009) which state that deferred tax expense does not affect Tax Avoidance.

\section{Conclusion}

Based on the results of the analysis and discussion, the leverage, capital intensity, and deferred tax expense simultaneously have a significant effect on tax avoidance. But partially. Leverage and Deferred tax expense do not affect Tax Avoidance. While Capital Intensity partially has a positive effect on effective tax rates or has a negative effect on Tax Avoidance.

For further research is expected to extend the research year and increase the research sample. Besides, researchers are expected to develop research by not removing companies that have experienced losses. The sector used can also be developed to be outside the manufacturing industry by adding variables that are considered to have an influence on tax avoidance such as corporate social responsibility, company size, sales growth, independent commissioners, audit committees, political connections or other independent variables.

\section{References}

Adisamartha, I. B. P. F., \& Noviari, N. (2015). Pengaruh Likuiditas, Leverage, Intensitas Persediaan Dan Intensitas Aset Tetap Pada Tingkat Agresivitas Wajib Pajak Badan. E-Jurnal Akuntansi Universitas Udayana, 13, 973-1000.

Alfina, I. T., Nurlaela, S., \& Wijayanti, A. (2018). The Influence of Profitability, Leverage, Independent Commissioner, and Company Size to Tax Avoidance. The 2nd International Conference on Technology, Education, and Social Science 2018, The 2nd IC(10), 102-106.

Darmadi, I. N. H., \& Zulaikha. (2013). Analisis Faktor Yang Mempengaruhi Manajemen Pajak Dengan Indikator Tarif Pajak Efektif. DIPONEGORO JOURNAL OF ACCOUNTING, 2(1), 1-12.

Darmawan, I. G. H., \& Sukartha, I. M. (2014). Pengaruh Penerapan Corporate
Governance , Leverage , Return On Assets, Dan Ukuran Perusahaan Pada Penghindaran Pajak. E-Jurnal Akuntansi Universitas Udayana. 9.1 (2014): 143 161, 1, 143-161.

Dharma, I. M. S., \& Ardiana, P. A. (2016). Pengaruh Leverage, Intensitas Aset Tetap, Ukuran Perusahaan, Dan Koneksi Politik Terhadap Tax Avoidance. E-Jurnal Akuntansi Universitas Udayana, 15, 584613.

Dharma, N. B. S., \& Noviari, N. (2017). Pengaruh Corporate Social Responsibility Dan Capital Intensity Terhadap Tax Avoidance. E-Jurnal Akuntansi Universitas Udayana, 18, 529-556.

Irianto, B. S., Sudibyo, Y. A., \& Wafirli, A. (2017). The Influence of Profitability, Leverage, Firm Size and Capital Intensity Towards Tax Avoidance. International Journal of Accounting and Taxation, 5(2), 33-41. https://doi.org/10.15640/ijat.v5n2a3

Kalbuana, N., Purwanti, T., \& Agustin, N. H. (2017). Pengaruh Kepemilikan Manajerial, Beban Pajak Tangguhan, Dan Tingkat Pajak Efektif Terhadap Penghindaran Pajak Di Indonesia. Magistra, No. 100 Th(100), 26-35.

Kurniasih, T., \& Sari, M. M. R. (2013). Pengaruh Return On Assets , Leverage , Corporate Governance, Ukuran Perusahaan Dan Kompensasi Rugi Fiskal Pada Tax Avoidance. Buletin Studi Ekonomi, 18(1), 58-66.

Meiza, R. (2015). Pengaruh Karakteristik Good Corporate Governance Dan Deferred Tax Expense Terhadap Tax Avoidance (Studi Empiris pada Perusahaan Manufaktur yang Listing di BEI tahun 2010-2013). Jurnal Elektronik Universitas Negeri Padang, 3 No 1.

Muzakki, M. R., \& Darsono. (2015). Pengaruh Corporate Social Responsibility Dan Capital Intensity Terhadap Penghindaran Pajak. Diponegoro Journal of Accounting, 4, 1-8. 
Philips, J. D. (2003). Coorporate Tax-planing effectiveness: The Role of Compensationbased increntives. The Accounting Review, 78(3), 847-874.

Pohan, C. A. (2016). Manajemen Perpajakan: Strategi Perencanaan Pajak \& Bisnis (Edisi Revisi). Jakarta: PT Gramedia Pustaka Utama.

Pohan, C. A. (2018). Pedoman Lengkap Pajak Internasional. Jakarta: Gramedia Pustaka Utama.

Pohan, H. T. (2009). Analisis pengaruh kepemilikan institusi, rasio tobin q, akrual pilihan, tarif efektif pajak, dan biaya pajak ditunda terhadap penghindaran pajak pada perusahaan publik. Jurnal Informasi, Perpajakan, Akuntansi Dan Keuangan Publik, 4(2), 113-135.

Ribeiro, A. I. M., Cerqueira, A., \& Brandão, E. (2015). The Determinants of Effective Tax Rates: Firms Characteristics and Corporate Governance. FEP-UP, School of Economics and Management, University of Porto, 1-54.

Richardson, G., \& Lanis, R. (2007). Determinants of the variability in corporate effective tax rates and tax reform : Evidence from Australia. Journal Of Accoungting And Public Policy 26 (2007) 689-704., 26, 689-704. https://doi.org/10.1016/j.jaccpubpol.2007 .10 .003
Rodríguez, E. F., \& Arias, A. M. (2012). Do Business Characteristics Determine an Effective Tax Rate? Evidence for Listed Companies in China and the United States. The Chinese Economy, 45 no. 6, 60-83. https://doi.org/10.2753/CES10971475450604

Sabli, N., \& Noor, R. M. (2012). Tax Planning and Coporate Governance. Proceeding International Conference on Business and Economic Reasearch.

Sarwono, J. (2016). Prosedur-Prosedur Analisis Populer Aplikasi Riset Skripsi dan Tesis dengan Eviews. Yogyakarta: Gava Media.

Sujarweni, W. V. (2015). SPSS Untuk Penelitian. Yogyakarta.

Tuerfia, R. A. (2017). Pengaruh Return On Asset, Leverage, Ukuran Perusahaan , Deferred Tax Expense Dan Kepemilikan Institusional Terhadap Tax Avoidance. Perbanas Institutional Repository.

Yunanda, D., \& Saifudin. (2016). Determinasi Return on Asset, Leverage, Ukuran Perusahaan, Kompensasi Rugi Fiskal dan Kepemilikan Institusi Terhadap Penghindaran Pajak (Studi Empiris Pada Perusahaan Manufaktur yang Terdaftar di BEI Tahun 2011 - 2014). Jurnal Penelitian Ilmu Ekonomi WIGA, 6(2), 131-143. 